\title{
Effect of polyols on thermostability of xylanase from a tropical isolate of Aureobasidium pullulans and its application in prebleaching of rice straw pulp
}

Wichanee Bankeeree ${ }^{1,2}$, Pongtharin Lotrakul ${ }^{2}$, Sehanat Prasongsuk ${ }^{2}$, Somporn Chaiareekij ${ }^{3}$, Douglas E Eveleigh ${ }^{4}$, Seung Wook Kim ${ }^{5^{*}}$ and Hunsa Punnapayak ${ }^{2^{*}}$

\begin{abstract}
In an attempt to find a thermostable xylanase enzyme for potential application in the pretreatment prior to $\mathrm{H}_{2} \mathrm{O}_{2}$ bleaching of paper pulp for industry, an extracellular xylanase from Aureobasidium pullulans CBS 135684 was purified 17.3 -fold to apparent homogeneity with a recovery yield of $13.7 \%$. Its molecular mass was approximately $72 \mathrm{kDa}$ as determined by SDS-PAGE. The optimal pH and temperature for activity of the purified enzyme were $\mathrm{pH} 6.0$ and $70^{\circ} \mathrm{C}$, respectively. The enzyme was relatively stable at $50^{\circ} \mathrm{C}$, retaining more than half of its original activity after 3-h incubation. The thermostability of the enzyme was improved by the addition of $0.75 \mathrm{mM}$ sorbitol prolonging the enzyme's activity up to 10 -fold at $70^{\circ} \mathrm{C}$. When the potential of using the enzyme in pretreatment of rice straw pulp prior to bleaching was evaluated, the greatest efficiency was obtained in a mixture containing xylanase and sorbitol. Treatment of the rice straw pulp with xylanase prior to treatment with $10 \%(\mathrm{v} / \mathrm{V}) \mathrm{H}_{2} \mathrm{O}_{2}$ and production of hand sheets increased the ISO sheet brightness by $13.5 \%$ and increased the tensile and tear strengths of the pulp by up to 1.16 and 1.71-fold, respectively, compared with pulps treated with $\mathrm{H}_{2} \mathrm{O}_{2}$ alone. The results suggested the potential application of the enzyme before the bleaching process of paper pulp when the maintenance of high temperature and enzyme stability are desirable.
\end{abstract}

Keywords: Endoxylanase; Thermostability; Sorbitol; Paper production; Black yeast; Color variants; Aureobasidium pullulans

\section{Introduction}

Xylanolytic enzymes form a group involved in the hydrolysis of xylans and arabinoxylans, the most abundant hemicellulosic polymers in plant biomass. Within this group, endo-1,4- $\beta$-xylanase is of special interest for use in various industrial applications, especially biopulping and bleaching. Xylanases are used in the pretreatment of pulp prior to bleaching to increase the liberation of lignin through the hydrolysis of hemicellulose (Suurnäkki et al. 2004). They have been employed to reduce the subsequent

\footnotetext{
* Correspondence: kimsw@korea.ac.kr; phunsa@chula.ac.th

${ }^{5}$ Department of Chemical and Biological Engineering, Korea University, Seoul 136-701, Republic of Korea

${ }^{2}$ Plant Biomass Utilization Research Unit, Department of Botany, Faculty of Science, Chulalongkorn University, Chulalongkorn, Bangkok 10330, Thailand Full list of author information is available at the end of the article
}

use of toxic chemicals, such as chlorine and hydrogen peroxide $\left(\mathrm{H}_{2} \mathrm{O}_{2}\right)$ (Beg et al. 2001). Although xylanases potentially offer a number of advantages over conventional chemical reagents, their application at an industrial scale remains limited. In the case of biobleaching, the incoming pulp for the enzyme-catalyzed process usually employs a high temperature $\left(70-100^{\circ} \mathrm{C}\right.$ ) (Beg et al. 2001), at which commercial xylanases, such as Cartazyme ${ }^{\circ}$, Ecopulp $\mathrm{X} 200^{\circ}$, and Resinase ${ }^{\circ}$, are not sufficiently stable (Viikari et al. 2002). Consequently, there is on-going search for more potent strains of xylanase producers, especially those that can produce thermostable enzymes with greater yields (Viikari et al. 2007).

Xylanolytic enzymes from Aureobasidium pullulans, generally known as black yeast, can be efficiently produced (Leathers 1986; Li et al. 1993; Ohta et al. 2010). 
The cellulase-free xylanases from $A$. pullulans produced efficiently (Leathers 1986; Ohta et al. 2010) are advantageous to the pulp and paper industry in that the hydrolysis of cellulose fibers is avoided resulting in greater yields of recovered pulp. From a number of xylanase-producing $A$. pullulans isolated from a range of different Thai habitats (Manitchotpisit et al. 2009), one strain (A. pullulans CBS 135684), a color variant, produced cellulase-free xylanase that was relatively thermostable. The stabilization of enzymes remains an important concern especially during thermal processing. The loss of enzyme activity throughout the elevated temperature ranges is related to changes of enzyme conformation (Cui et al. 2008; Fu et al. 2010). In order to prevent the conformational changes of the enzyme, addition of chemicals such as polyols to can promote numerous hydrogen bond or salt-bridge formation between amino acid residues which make the enzyme molecule more rigid, and therefore more resistant to the thermal unfolding (George et al. 2001; Costa et al. 2002). However, the selection of the appropriate additive depends on the nature of the enzyme. The objectives of this study were to (i) characterize the biochemical properties of purified thermally stable xylanase from an $A$. pullulans yeast strain, (ii) determine the effect of polyols on the thermostability of the enzyme, and (iii) investigate the potential application of the xylanase in the pulp bleaching of non-woody material. Rice straw was utilized as it is an alternative raw material that can be used for pulping with advantages of its porous fiber structure, greater concentration of holocellulose and less lignin levels (Rodrígueza et al. 2008). In addition, fibers from rice straw are shorter than softwood fibers which results in superior paper that can replace hardwood chemically treated pulps for printing and writing paper.

\section{Materials and methods}

\section{Organism and culture conditions}

Aureobasidium pullulans previously isolated, was maintained at the fungal culture collection of the Plant Biomass Utilization Research Unit, Department of Botany, Faculty of Science, Chulalongkorn University, Bangkok, Thailand (Manitchotpisit et al. 2009). It was deposited at the Centraalbureau voor Schimmelcultures, The Netherlands (CBS number 135684). The yeast was grown in yeast malt (YM) agar medium (Atlas 1993) at room temperature for 2 days and short-term stock cultures were stored at $4^{\circ} \mathrm{C}$. For long-term storage, the strain was stored at $-20^{\circ} \mathrm{C}$ in YM broth containing 20\% (v/v) glycerol.

\section{Xylanase production}

Seed culture was prepared by growing A. pullulans in basal medium (Leathers 1986) containing 1\% (w/v) glucose at $30^{\circ} \mathrm{C}$ with 150 -rpm agitation for $72 \mathrm{~h}$. The inoculum was adjusted to $2.5 \times 10^{6}$ cells. $\mathrm{mL}^{-1}$ and $100 \mu \mathrm{L}$ was transferred into a 250-mL Erlenmeyer flask containing $100 \mathrm{~mL}$ of basal medium supplemented with $1 \%(\mathrm{w} / \mathrm{v})$ agricultural wastes including wheat germ, wheat bran or corncob as the sole carbon source. The cultures were incubated at $30^{\circ} \mathrm{C}$ with 150 -rpm agitation for 3 days. The cells were separated from the culture broth by centrifugation $(18,000 \times \mathrm{g}, 20 \mathrm{~min})$ at $4^{\circ} \mathrm{C}$. The supernatant was used as the crude enzyme solution for further studies.

\section{Enzyme assay}

Xylanase and cellulase activities were assayed (Bailey et al. 1992) at $70^{\circ} \mathrm{C}$ using $1 \%(\mathrm{w} / \mathrm{v})$ beech wood xylan (Fluka, USA) and $0.5 \%(\mathrm{w} / \mathrm{v})$ carboxymethyl cellulose with the degree of substitution of 0.65 (Sigma, USA) as the substrates in $50 \mathrm{mM}$ acetate buffer ( $\mathrm{pH}$ 6.0). The amount of released reducing sugars was determined by the 3,5-dinitrosalicylic acid (DNS) method (Miller 1959). One unit (U) of xylanase/cellulase was defined as the amount of enzyme required to release $1 \mu \mathrm{mol}$ xylose/ glucose equivalent per min under the optimal conditions. Results are reported as the mean value of three replicates.

\section{Xylanase purification}

The extracellular xylanase was purified at $4{ }^{\circ} \mathrm{C}$. Culture supernatant $(500 \mathrm{~mL})$ from late log-phase $(72 \mathrm{~h})$ was concentrated ten-fold by ultrafiltration (10 kDa MW membrane cut-off, Amicon, Beverly, MA, USA) prior to precipitation using ammonium sulfate $(50-80 \%$ saturation). After recovery (centrifugation $10,000 \times \mathrm{g}$ for $20 \mathrm{~min}$ ), the pellet was dissolved in $20 \mathrm{~mL} 20 \mathrm{mM}$ Tris$\mathrm{HCl}$ buffer $(\mathrm{pH} 8.0)$ and dialyzed for $24 \mathrm{~h}$ against the same buffer. The enzyme solution ( $28 \mathrm{mg}$ total protein. $\mathrm{mL}^{-1}$ ) was applied ( $5 \mathrm{~mL}$ each run) to a pre-equilibrated anion exchange DEAE Sepharose FF (Sigma-Aldrich Co., USA) column. After washing the column with fivecolumn-volumes of $20 \mathrm{mM}$ Tris- $\mathrm{HCl}$ buffer $(\mathrm{pH} 8.0)$, elution was performed with a linear $\mathrm{NaCl}$ gradient ( 0 to 1.0 $\mathrm{M}$ over $50 \mathrm{~mL}$ ) in the same buffer at a flow rate of $1.0 \mathrm{~mL} \cdot \mathrm{min}^{-1}$. Five-mL fractions were collected and analyzed for xylanase activity and protein content. The protein content was estimated by the Lowry method (Lowry et al. 1951), using bovine serum albumin (BSA) as the standard. Fractions with xylanase activity were pooled, dialyzed against $50 \mathrm{mM}$ acetate buffer $(\mathrm{pH}$ 6), and then concentrated by ultrafiltration. Five $\mathrm{mL}$ of the concentrated enzyme solution $(\sim 4 \mathrm{mg}$ total protein $/ \mathrm{mL})$ was applied to a $30 \times 5 \mathrm{~cm}$ gel filtration column (Sephacryl S-100 HR, Sigma, USA) pre-equilibrated with $50 \mathrm{mM}$ acetate buffer ( $\mathrm{pH}$ 6.0). Elution was carried out at a flow rate of $0.5 \mathrm{~mL} . \mathrm{min}^{-1}$, collecting $3 \mathrm{~mL}$ fractions that were assayed for xylanase activity and protein content as described above. The protein profiles of the collected fractions were determined by resolution through SDS-PAGE 
(12.5\% (w/v) acrylamide resolving gel) as described (Laemmli 1970).

\section{Optimal conditions for xylanase activity}

The optimal temperature for the purified xylanase activity was determined by incubating the reaction mixture (4.5 U.mL ${ }^{-1}$ enzyme and $1 \% \mathrm{w} . \mathrm{v}^{-1}$ xylan, total volume $5 \mathrm{ml}$ ) at various temperatures, ranging from $40-90^{\circ} \mathrm{C}$ and at different $\mathrm{pHs}$. To determine the optimal $\mathrm{pH}$ for enzyme activity, $50 \mathrm{mM}$ sodium acetate buffers of $\mathrm{pH}$ 3.0-6.0 and $50 \mathrm{mM}$ phosphate buffers of $\mathrm{pH} 6.0-$ 10.0 were used. The relative activity was calculated as the percentage of enzyme activity in comparison to the maximum activity.

\section{Effects of ions}

To investigate the effect of ions on the enzyme activity, $\mathrm{CaCl}_{2}, \mathrm{CuCl}_{2}, \mathrm{MgCl}_{2}, \mathrm{FeSO}_{4 .} 7 \mathrm{H}_{2} \mathrm{O}, \mathrm{CoCl}_{2}, \mathrm{ZnCl}_{2}$ and EDTA were separately added to the reaction mixture at two different final concentrations of 1 and $10 \mathrm{mM}$, respectively, prior to performing the enzyme assay under the optimum conditions. The relative activity was calculated as a percentage of enzyme activity without the addition of ion.

\section{Substrate specificity}

The substrate specificity of the purified xylanase was tested with each of the followings; viz. beech wood xylan, oat spelt xylan, rice straw xylan, $\alpha$-cellulose and carboxymethyl cellulose (CMC). Oat spelt and rice straw xylans were prepared according to the method of Höijea et al. (2005). The xylanase activity was assayed under the optimum conditions.

\section{Effect of temperature on enzyme stability and thermodynamic analysis}

To determine the thermostability of the enzyme, it was incubated from $40-80^{\circ} \mathrm{C}$, in the absence of substrate, and residual xylanase activity was determined every $30 \mathrm{~min}$ for up to $180 \mathrm{~min}$. The data obtained from the thermal stability profile were used to analyze the thermodynamic parameters related to the xylanase activity. The half-life of the xylanase $\left(t_{1 / 2}, \mathrm{~min}^{-1}\right)$ was determined from Eq. (1) (Sadana 1995):

$$
t_{1 / 2}=\ln 2 / k_{d}
$$

The $D_{\mathrm{t}}$ values (decimal reduction time or time required to inactivate $90 \%$ of the original enzyme activity at a constant temperature) were calculated from Eq. (2):

$$
D_{t}=\ln 10 / k_{d}
$$

The activation energy for xylanase denaturation $\left(E_{\mathrm{d}}\right)$ was determined by an Arrhenius plot of the $\log$ denaturation rate constants $\left(\ln k_{\mathrm{d}}\right)$ versus the reciprocal of the absolute temperature in Kelvin (T) using Eq. (3) (Arrhenius 1889):

$$
\text { Slope }=-E_{d} / R \text {. }
$$

where $R$ is the gas constant $\left(8.314 \mathrm{~J} \cdot \mathrm{mol}^{-1} \cdot \mathrm{K}^{-1}\right)$.

The changes in enthalpy $\left(\Delta H^{\mathrm{o}}, \mathrm{kJ} \cdot \mathrm{mol}^{-1}\right)$, free energy $\left(\Delta G^{\mathrm{o}}, \mathrm{kJ} \cdot \mathrm{mol}^{-1}\right)$ and entropy $\left(\Delta S^{\mathrm{o}}, \mathrm{J} \cdot \mathrm{mol}^{-1} \cdot \mathrm{K}^{-1}\right)$ for the thermal denaturation of xylanase were determined using Eqs. (4)-(6) (Gummadi 2003)

$$
\begin{aligned}
& \Delta H^{o}=E_{\mathrm{d}}-R T, \\
& \Delta G^{o}=-\mathrm{R} T \ln \left(k_{d} \mathrm{~h} / k_{\mathrm{B}} T\right), \\
& \Delta S^{o}=\left(\Delta H^{o}-\Delta G^{o}\right) / T .
\end{aligned}
$$

where $h$ is the Planck constant $\left(11.04 \times 10^{-36} \mathrm{~J} . \mathrm{min}\right)$ and $k_{\mathrm{B}}$ is the Boltzman constant $\left(1.38 \times 10^{-23} \mathrm{~J} . \mathrm{K}^{-1}\right)$.

\section{Effect of polyols on xylanase thermostability}

In order to improve the thermal stability of the xylanase, polyols including ethylene glycol (2C), glycerol (3C), xylitol (5C), sorbitol (6C) and mannitol (6C) were added to separate enzyme solutions at $0.5 \mathrm{M}$ final concentration prior to incubation at $70^{\circ} \mathrm{C}$. Aliquots were withdrawn every $30 \mathrm{~min}$, ice-cooled and then the residual xylanase enzyme activity was assayed under the optimal conditions. The stability of the enzyme was expressed as a percentage of residual activity (\% RA) compared with activity of the initial enzyme activity (before incubation and no polyols). The polyol that most improved the thermostability was selected for further study over a range of concentration on the optimal $(0.25-1.00 \mathrm{M})$ at $70^{\circ} \mathrm{C}$.

\section{Pulp treatment and property determination}

The rice straw was collected from a local rice field in Suphanburi province, Thailand. The pulping of rice straw was carried out with the soda process (Chaiarrekij et al. 2011) before being extensively washed with tap water to remove the alkali. The xylanase pretreatment (18.6 U crude xylanase. $\mathrm{g}^{-1}$ dry pulp) with or without sorbitol at a final concentration of $0.75 \mathrm{M}$, was performed in transparent plastic bags with $10 \%(\mathrm{w} / \mathrm{v})$ rice straw pulp suspended in $50 \mathrm{mM}$ sodium acetate buffer ( $\mathrm{pH}$ 6.0). The reaction was performed at $70^{\circ} \mathrm{C}$ for $2 \mathrm{~h}$ (Viikari et al. 2007). Reducing sugars in the hydrolysates were determined by the DNS method. For $\mathrm{H}_{2} \mathrm{O}_{2}$ treatment, the enzyme-treated pulp (or the enzymeuntreated pulp as the control) was transferred to the $\mathrm{H}_{2} \mathrm{O}_{2}$ solution $(10 \%(\mathrm{v} / \mathrm{v})$ final concentration) and incubated for $1 \mathrm{~h}$ at the same temperature. The resultant bleached pulp was made into 60 g.m ${ }^{-2}$ hand sheets on a Rapid-Köthen sheet former (RK-2A KWT, PTI, Austria) 
according to the ISO Standard Method 5269-2. The brightness and opacity of the hand sheets were measured using an optical tester (Color Touch PC, Technidyne, U.S.A.), based on the ISO Standard Methods 2470 and 2471, respectively. The tensile and tear indexes were determined after tensile strength and tear resistance were measured using a tensile strength tester (Strograph E-S, Toyo Seiki, Japan) and a tear strength tester (Protear, Thwing-Albert, U.S.A.) according to TAPPI Standard Method T 494 om-01 and T414 om-04, respectively. Fiber morphology was also analyzed using a fiber quality analyzer (FQA LDA02, OpTest Equipment, Canada) according to the TAPPI Standard Method T271 om-12. Untreated pulp was used as the control.

\section{Data analysis}

Statistical differences among the means of data were calculated using one-way analysis of variance (ANOVA) and Duncan's Multiple Range Test (DMRT) or Student's t-test (2 tailed) with the SPSS 17.0 software package (SPSS Inc., Chicago, U.S.A.). Differences at $P<0.05$ were considered significant.

\section{Results and discussion}

\section{Xylanase production}

Xylanase production by $A$. pullulans CBS 135684 was investigated using several agricultural wastes with high hemicellulose contents as substrates including wheat germ, wheat bran and corncob (Goering and Van Soest 1970). The maximum xylanase production $\left(4.10 \mathrm{U} \cdot \mathrm{mL}^{-1}\right)$ was observed using $1 \%(\mathrm{w} / \mathrm{v})$ corncob for 3 days at room temperature $\left(28 \pm 2^{\circ} \mathrm{C}\right)$ (Table 1$)$. Consequently, corncob was selected for further xylanase production. Even though the xylanase production from corncob was 1.76fold lower than that obtained with beech wood xylan (7.23 U.mL $\mathrm{mL}^{-1}$ ), corncob was practically more attractive due to its lower cost (Benedetti et al. 2013). Similar approaches have been used with Colletotrichum graminicola (Zimbardi et al. 2013) and Aspergillus nidulans (Reis et al. 2003). However, the xylanases from these microbes included cellulase activity. None was detectable in the $A$. pullulans xylanase.

\begin{tabular}{|c|c|}
\hline Agricultural wastes & Xylanase activity $\left(U \cdot \mathrm{mL}^{-1}\right)^{*}$ \\
\hline Wheat germ & $3.25 \pm 0.13^{b}$ \\
\hline Wheat bran & $2.59 \pm 0.08^{\mathrm{a}}$ \\
\hline Corncob & $4.10 \pm 0.10^{c}$ \\
\hline
\end{tabular}

*Mean \pm one standard deviation derived from three replicates $(N=3)$. Different superscript letter $(a, b, c)$ in the same column indicated the values were significantly different (ANOVA and DMRT, $P<0.05$ ).

\section{Purification of the native extracellular xylanase from $A$. pullulans CBS 135684}

The summary of the purification steps are shown in Table 2. DEAE-Sepharose column chromatography yielded two peaks of xylanase activity as isozymes (Figure 1). The result is similar to that reported for the color variant $A$. pullulans NRRL Y-2311-1 (Li et al. 1993) and A. pullulans ATCC 20504 (Tanaka et al. 2006) which secreted at least two isozymes of xylanase. The second peak, which represented the major portion ( $60 \%$ total) of xylanase activity, was further fractionated using Sephacryl S-100 gel filtration chromatography to yield a single xylanase peak. The purified protein showed a single band of $\sim 72 \mathrm{kDa}$ on SDSPAGE which coincided with the estimate by Sephacryl S100 gel filtration chromatography (Figure 2). The overall level of recovery was approximately $13.7 \%$ with a 17.3 -fold enrichment and a specific activity of $41.4 \mathrm{U}_{\mathrm{mg}}{ }^{-1}$ protein.

\section{Optimal conditions for xylanase activity}

The effects of $\mathrm{pH}$ and temperature on the activity of the purified xylanase are summarized in Figure 3 . The purified xylanase was active over a broad $\mathrm{pH}$ range with a maximum activity at $\mathrm{pH} 6$, and $\geq 80 \%$ and $\geq 70 \%$ maximal activity were observed at $\mathrm{pH} 4-8$ and $\mathrm{pH} 4-10$, respectively. The enzyme activity dramatically decreased at $\mathrm{pH} 3(20 \%$ to $40 \%$ maximal activity at $50^{\circ} \mathrm{C}$ and $70^{\circ} \mathrm{C}$, respectively). Conversely the xylanase activity was significantly increased (at each $\mathrm{pH}$ ) as the incubation temperature was increased from $40^{\circ} \mathrm{C}$ to the optimal at $70^{\circ} \mathrm{C}(3.64 \pm 0.12$ to $\left.4.60 \pm 0.13 \mathrm{U} \cdot \mathrm{mL}^{-1}\right)$ at $\mathrm{pH} 6$. A significantly lower xylanase activity was noted at $90^{\circ} \mathrm{C}\left(2.89 \pm 0.05 \mathrm{U} \cdot \mathrm{mL}^{-1}\right)$.

The optimal $\mathrm{pH}(\mathrm{pH} 6.0)$ and temperature $\left(70^{\circ} \mathrm{C}\right)$ of the purified xylanase were similar to those of the crude enzyme (data not shown). Xylanases that are active in an alkaline environment and at high temperature are uncommon in yeasts (Techapun et al. 2002). Even among A. pullulans strains, previous reports on xylanase from A. pullulans (NRRL Y-2311-1 and ATCC 42023) showed that the enzymes were active at acidic $\mathrm{pH}$ (4.5-4.8) (Leathers 1989; Li et al. 1993; Vadi et al. 1996). Alkaline tolerant and thermotolerant xylanases have been reported in a number of bacteria, including Bacillus sp. (Zheng et al. 2000) and Clostridium absonum CFR-702 (Rani and Nand 2000). With its broad optimum pH and thermophilic properties, the xylanase from A. pullulans CBS 135684 may be used in several industrial applications not only for pulp bleaching but also for the bioconversion of lignocellulosic materials that is more optimally performed at a high $\mathrm{pH}$ and temperature (Parachin et al. 2009).

\section{Effects of metal ions}

The effects of EDTA and six cations commonly found in pulp on the xylanase activity are summarized in Table 3. 
Table 2 Purification steps of xylanase isolated from A. pullulans CBS 135684 cultivated in basal medium containing 1\% (w/v) corncob

\begin{tabular}{|c|c|c|c|c|c|}
\hline Purification steps & Total protein $(\mathrm{mg})^{*}$ & Total activity $(\mathrm{U})^{\mathrm{a},{ }^{*}}$ & Specific activity $\left(U \cdot \mathrm{mg}^{-1}\right)^{*}$ & Purification (fold)* & Yield (\%)* \\
\hline Culture supernatant & $2,030.00 \pm 32.24$ & $4,850.00 \pm 36.42$ & $2.39 \pm 0.04$ & 1.00 & 100.00 \\
\hline Ultrafiltration & $1,376.00 \pm 26.18$ & $4,431.00 \pm 27.31$ & $3.22 \pm 0.06$ & 1.35 & 91.40 \\
\hline $\begin{array}{l}\left(\mathrm{NH}_{4}\right)_{2} \mathrm{SO}_{4} \text { precipitation } \\
\text { (50-80\% saturation) }\end{array}$ & $560.00 \pm 1.24$ & $2,440.00 \pm 14.24$ & $4.36 \pm 0.02$ & 1.81 & 50.30 \\
\hline DEAE-Sepharose & $21.00 \pm 1.04$ & $834.00 \pm 9.84$ & $39.70 \pm 1.76$ & 16.60 & 17.20 \\
\hline Sephacryl S-100 & $16.00 \pm 1.24$ & $662.00 \pm 10.46$ & $41.40 \pm 2.85$ & 17.30 & 13.60 \\
\hline
\end{tabular}

${ }^{\mathrm{a}} 1 \mathrm{U}=$ the amount of enzyme required to release $1 \mu \mathrm{mol}$ xylose equivalent per min under the assay conditions.

*Mean \pm one standard deviation derived from three replicates $(N=3)$.

At $1 \mathrm{mM}$, none of the metal ions significantly affected the enzyme, except $\mathrm{Ca}^{2+}$. The presence of $\mathrm{Ca}^{2+}$ was equally stimulating at 1 and $10 \mathrm{mM}$, whilst $\mathrm{Co}^{2+}$ and $\mathrm{Mg}^{2+}$ significantly enhanced the xylanase activity only at $10 \mathrm{mM}$. The treatment of purified xylanase with EDTA did not significantly decrease the xylanase activity, suggesting that the divalent cation was not essential for xylanase activity. The presence of $\mathrm{Zn}^{2+}$ had no effect on xylanase activity which was different from a previous report that a purified xylanase from $A$. pullulans ATCC 42023 was inhibited by $\mathrm{Zn}^{2+}$ and $\mathrm{Co}^{2+}$ (Vadi et al. 1996). In contrast, $\mathrm{Fe}^{2+}$ and $\mathrm{Cu}^{2+}$ showed a dose-dependent inhibitory effect against the enzyme, which was significant at $10 \mathrm{mM}$. Inactivation of xylanases by $\mathrm{Fe}^{2+}$ and $\mathrm{Cu}^{2+}$ has been reported among other fungi including Aspergillus usamii (Zhou et al. 2009) and Aspergillus awamori VTCC-F312 (Do et al. 2012). These ions were suggested to react with the thiol groups, carboxyl groups and histidine residues in the enzymes and so destroy its active protein structure (Lama et al. 2004).

\section{Substrate specificity}

The activity of the purified xylanase on various substrates was determined. The enzyme showed high specificity towards different xylans. Among them, the highest activity was observed with $1 \%(\mathrm{w} / \mathrm{v})$ beech wood xylan $\left(4.10 \pm 0.1 \mathrm{U} \cdot \mathrm{mL}^{-1}\right)$, followed by oat spelt xylan $(3.87 \pm$ $\left.0.23 \mathrm{U} \cdot \mathrm{mL}^{-1}\right)$ and rice straw xylan $\left(3.48 \pm 0.12 \mathrm{U} \cdot \mathrm{mL}^{-1}\right)$, respectively. It might be due to the fact that the substitution of side chains in the cereal xylans was higher than that of the hardwood xylan (Voragen et al. 1992). In contrast, no activity was observed when using $\alpha$-cellulose or $\mathrm{CMC}$ as substrate which indicated that the xylanase enzyme from $A$. pullulans CBS 135684 was cellulase-free (data not shown).

\section{Thermostability of the purified xylanase}

Stabilization of enzymes, especially during thermal processes, remains an important concern in modern biotechnology. The loss of enzyme activity during exposure to elevated temperatures is related to the significant changes in the enzyme conformation (Cui et al. 2008), and these can be estimated according to the Arrhenius equation and thermodynamic parameters (Marangoni 2003). In this study, the thermal stability of the xylanase from A pullulans was assessed at $40-70^{\circ} \mathrm{C}$ at $\mathrm{pH}$ 6.0. The purified enzyme was found to be relatively stable at $40^{\circ} \mathrm{C}$ and $45^{\circ} \mathrm{C}$ with more than $80 \%$ of its original activity remaining after $3 \mathrm{~h}$ incubation (Figure 4 ). After incubation for $60 \mathrm{~min}$ at $50^{\circ} \mathrm{C}, 55^{\circ} \mathrm{C}, 60^{\circ} \mathrm{C}, 65^{\circ} \mathrm{C}$ or $70^{\circ} \mathrm{C}$

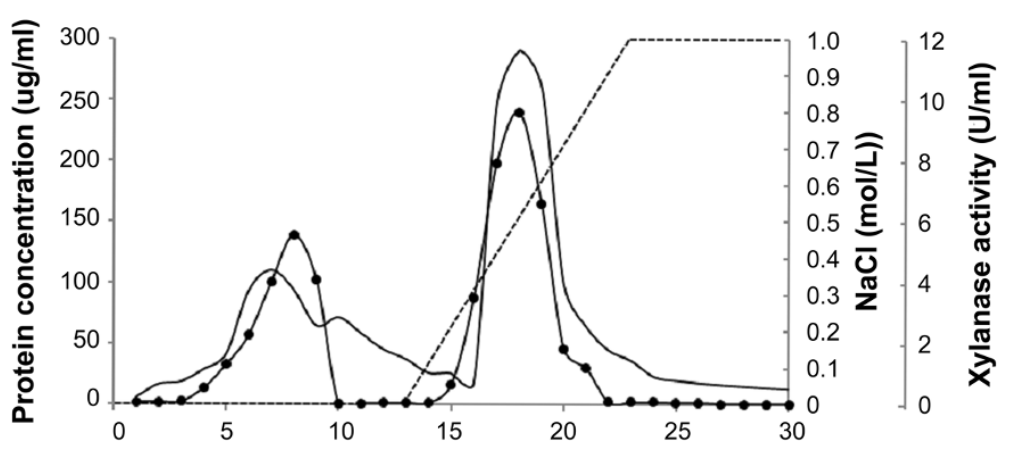

Figure 1 Chromatographic separation of xylanases from A. pullulans CBS 135684 cultivated in basal medium containing 1\% (w/v) corncob using DEAE-Sepharose $\left[1.6 \times 45 \mathrm{~cm}\right.$ column - fast flow at $1.0 \mathrm{~mL} . \mathrm{min}^{-1} .5 \mathrm{ml}$ fractions.]. $\bullet$, xylanase activity; (---), NaCl gradient; $(-)$, protein concentration. 


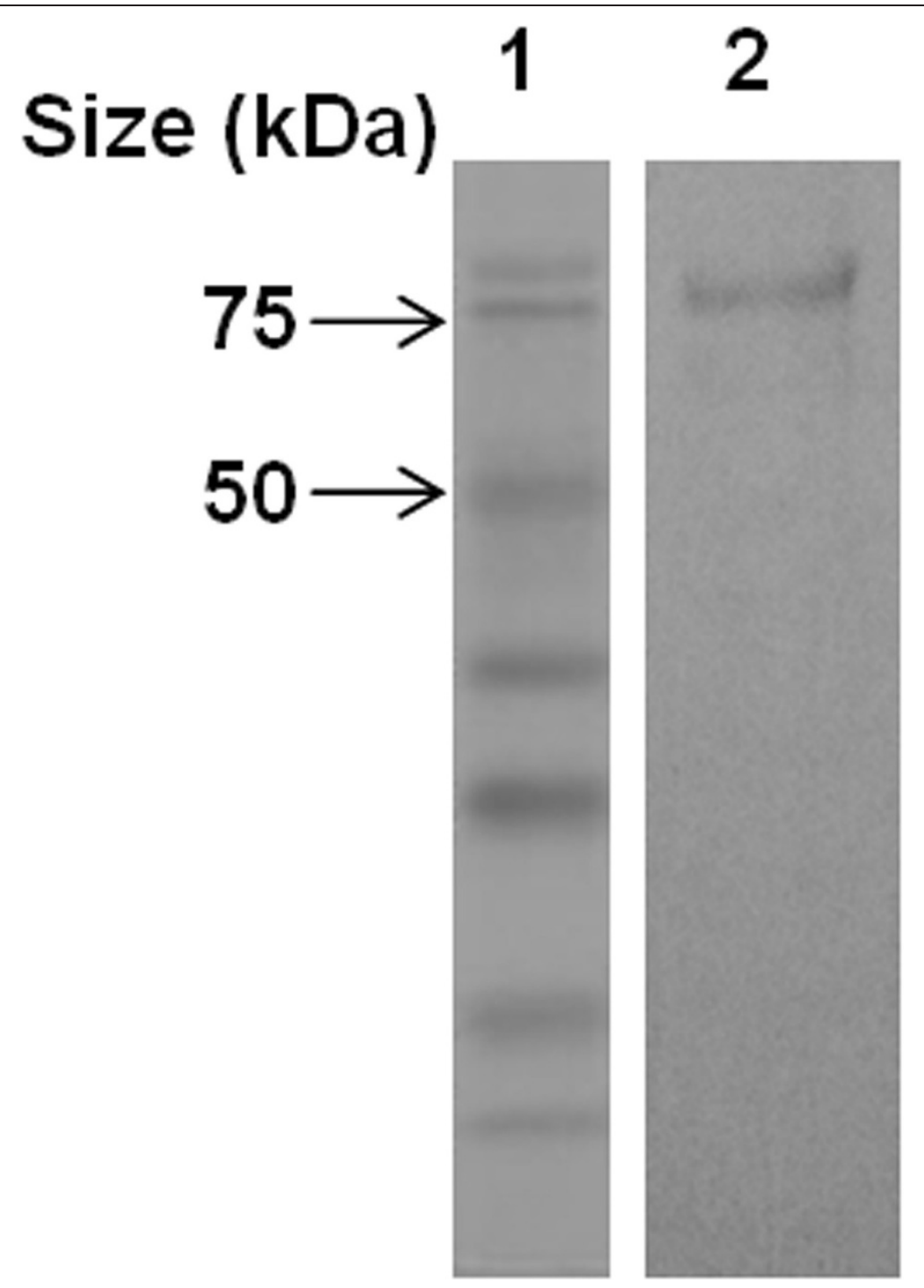

Figure 2 SDS-PAGE analysis of the purified xylanase from $A$. pullulans CBS 135684 cultivated in basal medium containing 1\% (w/v) corncob. The enzyme ( $20 \mu \mathrm{g}$ protein) was electrophoresed at pH 8.3 on a 12.5\% acrylamide gel and stained with Coomassie Brilliant Blue R250. Lane 1: MW standards; Lane 2: purified xylanase. The figure was a representative of repeated experiment.

some $95 \%, 84 \%, 60 \%, 40 \%$ or $23 \%$ of the initial enzyme activity remained, respectively. However, the enzyme quickly lost its activity at $70^{\circ} \mathrm{C}$ and especially at $75^{\circ} \mathrm{C}$ and $80^{\circ} \mathrm{C}$, it had $<20 \%$ residual activity after $30 \mathrm{~min}$ (data not shown). The semi-logarithmic plots of the residual enzyme activity versus incubation time were linear only at ranges between 50 to $70^{\circ} \mathrm{C}$, with $\mathrm{R}^{2}>0.97$, indicating that the inactivation can be expressed as first order kinetics (Figure 5). The rate of enzyme deactivation $\left(k_{\mathrm{d}}\right)$ evaluated from the slope of these plots; increased at higher temperatures (Table 4). The activation energy for irreversible inactivation $\left(E_{\mathrm{d}}\right)$ of the xylanase was determined to be $86.1 \mathrm{~kJ}^{-\mathrm{mol}^{-1}}$ from the Arrhenius plot (Figure 5). Increasing the temperature decreased the half-life $\left(t_{1 / 2}\right)$ of xylanase. The enthalpy of activation of the thermal denaturation $(\Delta H)$ was decreased at $70^{\circ} \mathrm{C}$, which clearly indicated that less energy was required for the thermal denaturation of the enzyme at a higher temperature. The Gibbs free energy $(\Delta G)$ for the thermal unfolding increased from 106.0-107.6 kJ.mol ${ }^{-1}$ with increasing temperature from $50-70^{\circ} \mathrm{C}$. Although the unfolding of the enzyme structure was accompanied by an increase in the disorder or entropy of deactivation, the xylanase from $A$. pullulans CBS 135684 had negative entropy $(\Delta S)$, suggesting that the native form was in a more ordered state. The negative entropy change indicated aggregation of the xylanase in which a few interand/or intra-molecular bonds were formed, and thus the state of order of the system increased (Anema and McKenna 1996). 


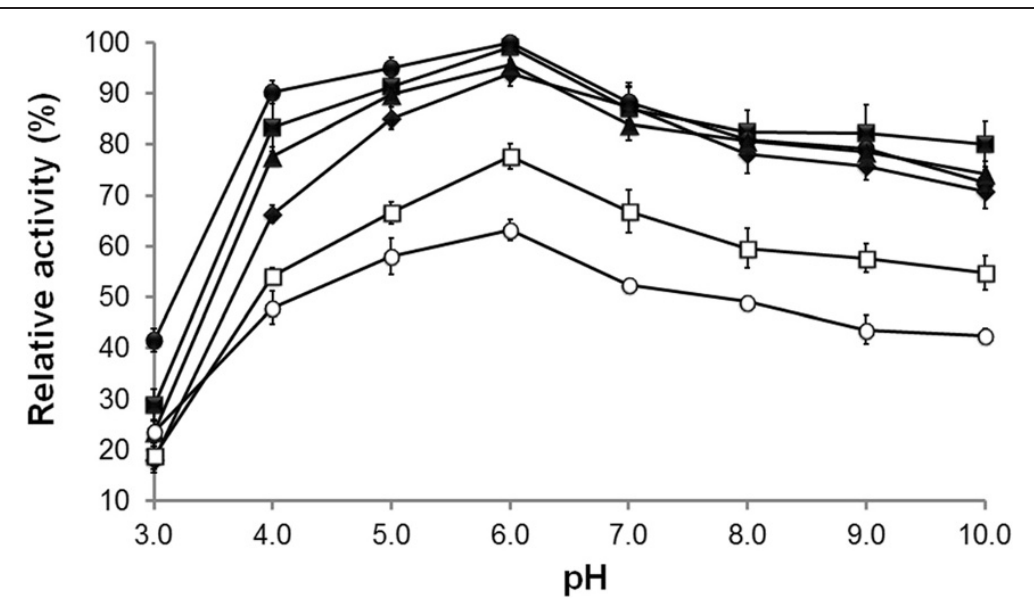

Figure 3 Effect of $\mathrm{pH}$ and temperature on activity of the purified xylanase from A. pullulans CBS 135684 cultivated in basal medium containing $1 \%(\mathbf{w} / \mathbf{v})$ corncob. Reactions were conducted for 30 mins with $1 \%(\mathrm{w} / \mathrm{v})$ beech wood xylan in $50 \mathrm{mM}$ of sodium acetate buffers $(\mathrm{pH} 3.0-6.0)$ or phosphate buffers ( $\mathrm{pH} 6.0-10.0)$ at various temperatures including $50^{\circ} \mathrm{C}(\boldsymbol{\bullet}), 60^{\circ} \mathrm{C}(\mathbf{-}), 70^{\circ} \mathrm{C}(\cdot), 80^{\circ} \mathrm{C}(\mathbf{\Delta})$ and $90^{\circ} \mathrm{C}(0)$. The relative activity was calculated as the percentage of enzyme activity assayed in $50 \mathrm{mM}$ sodium acetate buffers $(\mathrm{pH} 6.0)$ at $70^{\circ} \mathrm{C}$. Experiments were performed in triplicate $(\mathrm{N}=3)$ and error bars indicated standard deviations.

\section{Effect of polyols on the thermostability of the purified xylanase}

In order to avoid thermal inactivation, the addition of small compounds to an enzyme solution can provide a practical means of increasing the enzyme stability by changing its microenvironment ( $\mathrm{Pal}$ and Khanum 2010). For example, the addition of polyols improves the thermostability of enzymes from fungi (George

Table 3 Effects of different cations with the purified xylanase from A. pullulans CBS 135684 cultivated in basal medium containing $1 \%(\mathrm{w} / \mathrm{v})$ corncob

\begin{tabular}{lcc}
\hline Additive & \multicolumn{2}{c}{$\begin{array}{c}\text { Relative enzyme activity (\%) } \\
\text { concentration of: }\end{array}$} \\
\cline { 2 - 3 } & $\mathbf{1 ~ m M}$ & $\mathbf{1 0 ~ m M}$ \\
\hline None & $100.0 \pm 2.0^{\mathrm{abc}, \mathrm{NS}}$ & $100.0 \pm 1.0^{\mathrm{C}, \mathrm{NS}}$ \\
$\mathrm{Fe}^{2+}$ & $99.9 \pm 4.5^{\mathrm{abc}, 2}$ & $74.1 \pm 1.2^{\mathrm{B}, 1}$ \\
$\mathrm{Mg}^{2+}$ & $105.9 \pm 3.0^{\mathrm{c}, 1}$ & $111.7 \pm 5.1^{\mathrm{E}, 2}$ \\
$\mathrm{Ca}^{2+}$ & $112.4 \pm 1.5^{\mathrm{d}, \mathrm{NS}}$ & $112.4 \pm 2.8^{\mathrm{E}, \mathrm{NS}}$ \\
$\mathrm{Cu}^{2+}$ & $95.5 \pm 2.2^{\mathrm{a}, 2}$ & $29.9 \pm 2.7^{\mathrm{A}, 1}$ \\
$\mathrm{Co}^{2+}$ & $103.4 \pm 4.1^{\mathrm{bc}, 1}$ & $106.1 \pm 3.5^{\mathrm{D}, 2}$ \\
Zn $^{2+}$ & $99.2 \pm 2.5^{\mathrm{ab}, \mathrm{NS}}$ & $98.4 \pm 2.4^{\mathrm{C}, \mathrm{NS}}$ \\
$\mathrm{EDTA}^{2+}$ & $100.9 \pm 5.3^{\mathrm{abc}, \mathrm{NS}}$ & $99.6 \pm 1.2^{\mathrm{C}, \mathrm{NS}}$ \\
\hline
\end{tabular}

The data were calculated from relative activity at different concentration of additives. The enzyme activity was assayed at $70^{\circ} \mathrm{C}$ for $30 \mathrm{~min}$ with $1 \%(\mathrm{w} / \mathrm{v})$ beech wood xylan in $50 \mathrm{mM}$ acetate buffer ( $\mathrm{pH} 6.0$ ).

*One hundred percent activity corresponded to the activity of the enriched xylanase under standard assay conditions (without additive). Mean \pm one standard deviation derived from three replicates $(N=3)$. Different superscript letter $(a, b, c, A, B, C, D, E)$ in the same column indicated the values were significantly different (ANOVA and DMRT, $P<0.05$ ) and different superscript number in the same row $(1,2)$ indicated the values were significantly different (Student's t-test, $P<0.05$ ).

NS = not significantly different. et al. 2001; Kang-li and Da-nian 2013; Bourneow et al. 2012; Samborska et al. 2006; Lemos et al. 2000), including xylanases from Trichoderma reesei QM 9414 (Cobos and Estrada 2003) and Aspergillus niger DFR-5 (Pal and Khanum 2010). The selection of the appropriate polyol depends on the nature of the enzyme. In this study, the addition of each of five polyols showed a significant $(P<0.05)$ protection against thermal denaturation in comparison with the control (Figure 6a), but they differ in their degree of protection afforded. The highest protective effect was by sorbitol $(6 \mathrm{C}, 6 \mathrm{OH})$ which resulted in $64.2 \%$ retention of the original enzyme activity after $180 \mathrm{~min}$ at $70^{\circ} \mathrm{C}$, some 14.5 -fold higher than that for the enzyme alone. Xylitol (5C, $5 \mathrm{OH})$ and ethylene glycol $(2 \mathrm{C}, 2 \mathrm{OH})$ gave the next highest protection, but respectively some 1.2- and 1.3fold less effective than sorbitol. Mannitol (C6, 6OH) and glycerol $(3 \mathrm{C}, 3 \mathrm{OH})$ were far less effective protectants (2.3- and 5.1-fold less effective than sorbitol, respectively). Several studies have been suggested that the molecular size and number of hydroxyl groups per polyol molecule are play a crucial role in mediating the protection against thermal inactivation (Lemos et al. 2000). However, there is no clear pattern evident in this case. It has further been suggested that the protective role of polyols is due to their capability to form hydrogen bonds that support and stabilize the native conformation of the enzyme to make it more resistant to thermal unfolding (Cobos and Estrada 2003). In this study sorbitol was clearly the best thermoprotectant at $0.5 \mathrm{M}$. The effect of different sorbitol concentrations on the thermostability of the purified xylanase was also evaluated. Increasing the sorbitol concentration up to 


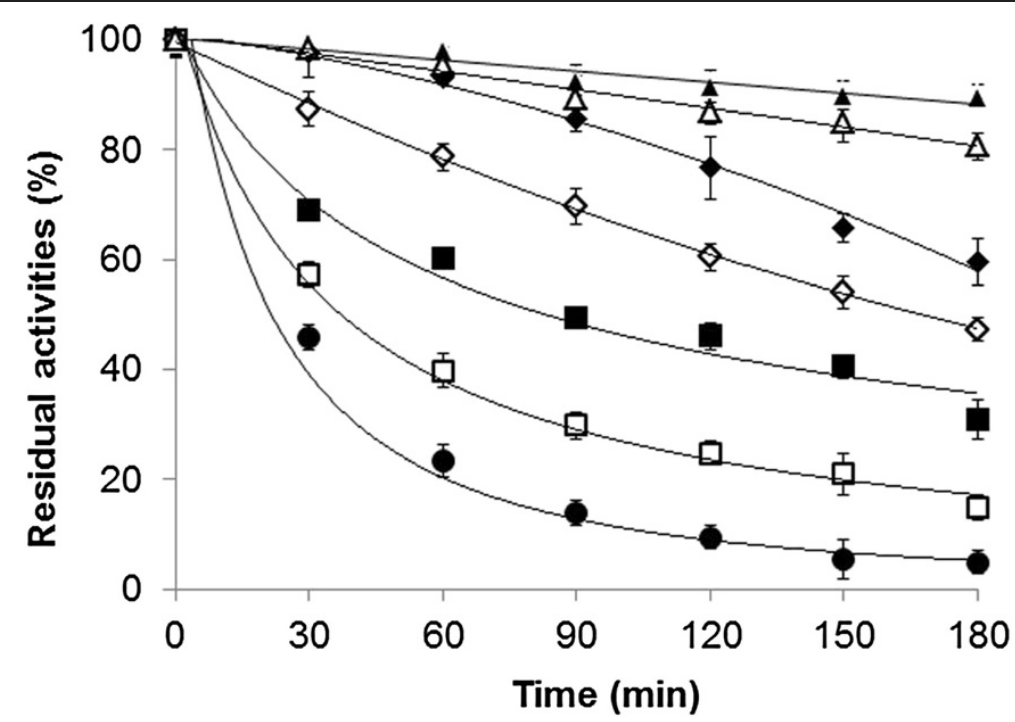

Figure 4 Thermostability profile of the purified xylanase from A. pullulans CBS 135684 cultivated in basal medium containing $1 \%$ corncob. The purified enzyme solubilized in $50 \mathrm{mM}$ of sodium acetate buffers $(\mathrm{pH} 6.0)$ and separately incubated at $40^{\circ} \mathrm{C}(\boldsymbol{\Delta}), 45^{\circ} \mathrm{C}(\Delta), 50^{\circ} \mathrm{C}(\boldsymbol{})$, $55^{\circ} \mathrm{C}(\bullet), 60^{\circ} \mathrm{C}(\mathbf{\bullet}), 65^{\circ} \mathrm{C}(\square)$ and $70^{\circ} \mathrm{C}(\cdot)$ prior to enzyme assay at standard $\mathrm{pH}$ and optimal temperature. The residual xylanase activity was calculated as the percentage of initial enzyme activity (before incubation). Experiments were performed in triplicate $(N=3)$ and error bars indicated standard deviations.

$0.75 \mathrm{M}$ further improved the thermostability of the purified xylanase with $\sim 80 \%$ of the original activity remaining after $180 \mathrm{~min}$ at $70^{\circ} \mathrm{C}$ (Figure 6b). At $1.0 \mathrm{M}$ sorbitol, no significant further change in the xylanase activity was observed. While the effects of sorbitol on the thermostability of xylanase have been recognized in filamentous fungi including Aspergillus awamori (at $52^{\circ} \mathrm{C}$ ) (Lemos et al. 2000) and bacteria including Bacillus amyloliquefaciens (at $80^{\circ} \mathrm{C}$ ) (Breccia et al. 1998) and Thermomonospora sp. (at $80^{\circ} \mathrm{C}$ ) (George et al. 2001), such effects on the thermostability of xylanase from yeast has not yet been reported.

\section{Prebleaching of rice straw pulp}

Although the xylanase from $A$. pullulans CBS 135684 was relatively unstable at the temperature higher than $50^{\circ} \mathrm{C}$

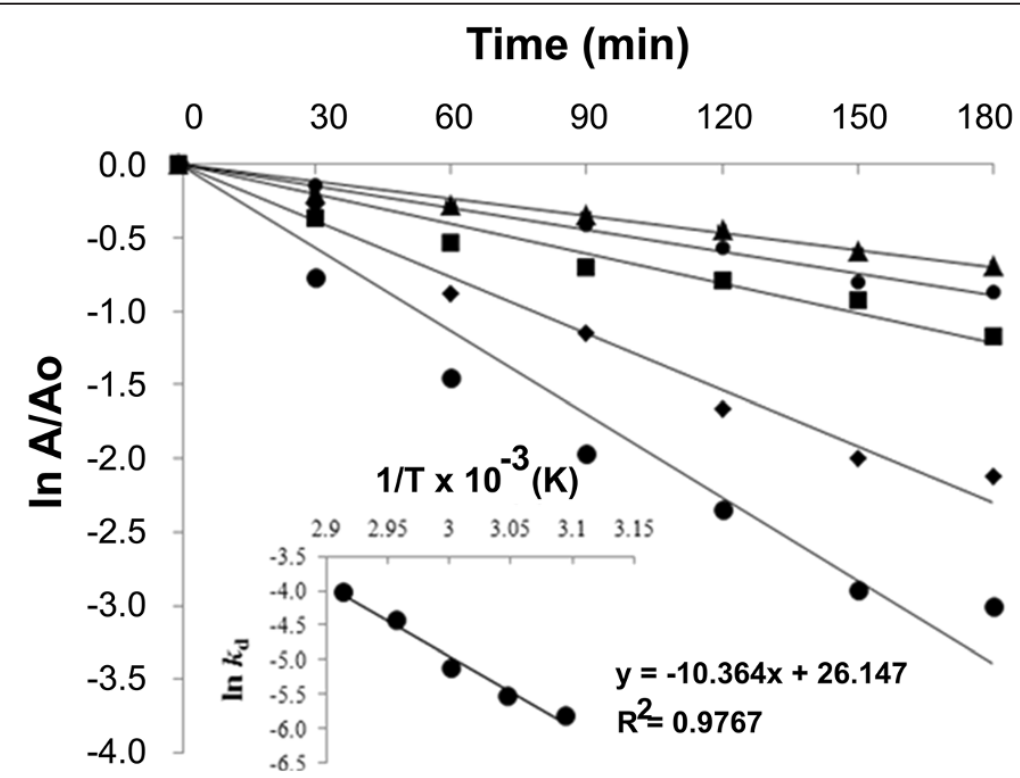

Figure 5 First order thermal deactivation of the purified xylanase from A. pullulans CBS 135684 cultivated in basal medium containing $1 \%(\mathrm{w} / \mathrm{v})$ corncob at $50^{\circ} \mathrm{C}(\bullet), 55^{\circ} \mathrm{C}(\bullet), 60^{\circ} \mathrm{C}(\square), 65^{\circ} \mathrm{C}(\square)$ and $70^{\circ} \mathrm{C}(\bullet)$. Inset shows the Arrhenius plot for the calculation of activation energy $\left(E_{d}\right)$ for thermal denaturation. Experiments were performed in triplicate $(N=3)$ and error bars indicated standard deviations. 
Table 4 Thermodynamic parameters for the irreversible thermal inactivation of the purified xylanase from $A$. pullulans CBS 135684 cultivated in basal medium containing $1 \%(w / v)$ corncob

\begin{tabular}{|c|c|c|c|c|c|c|}
\hline Temperature $\left({ }^{\circ} \mathrm{C}\right)$ & $k_{\mathrm{d}}\left(\min ^{-1}\right)$ & $t_{1 / 2}(\min )$ & $D_{\mathrm{t}}(\min )$ & $\Delta H^{\circ}\left(\mathrm{kJ} \cdot \mathrm{mol}^{-1}\right)$ & $\Delta G^{\circ}\left(\mathrm{kJ}^{\mathrm{mol}} \mathrm{mo}^{-1}\right)$ & $\Delta S^{\circ}\left(\mathrm{J} \cdot \mathrm{mol}^{-1} \cdot \mathrm{K}^{-1}\right)$ \\
\hline 50 & 0.003 & 231 & 768 & 83.450 & 105.960 & -0.070 \\
\hline 55 & 0.004 & 173 & 576 & 83.400 & 106.850 & -0.071 \\
\hline 60 & 0.006 & 116 & 384 & 83.360 & 107.400 & -0.072 \\
\hline 65 & 0.012 & 58 & 192 & 83.320 & 107.100 & -0.070 \\
\hline 70 & 0.018 & 39 & 128 & 83.280 & 107.570 & -0.071 \\
\hline
\end{tabular}

The data were calculated from residual activity at different temperatures. The enzyme activity was assayed at $70^{\circ} \mathrm{C}$ for $30 \mathrm{~min}$ with $1 \%$ (w/v) beech wood xylan in $50 \mathrm{mM}$ acetate buffer ( $\mathrm{pH} 6.0)$.

Experiments were performed in triplicate $(N=3) . E_{\mathrm{d}}=86.13 \mathrm{~kJ} \cdot \mathrm{mol}^{-1}, \Delta H^{\circ}=$ Variations in enthalpy; $\Delta G^{\circ}=V_{a r i a t i o n s}$ in free energy; $\Delta S^{\circ}=V^{2}$ ariations in entropy in free energy and $\Delta S^{\circ}=$ Variations in entropy.

(Figure 4), its stability could be improved by the addition of $0.75 \mathrm{M}$ sorbitol (Figure 6). Half-life of the enzyme at $70^{\circ} \mathrm{C}$ was prolonged in the presence of sorbitol which was comparable to that at $50^{\circ} \mathrm{C}$ without sorbitol (data not shown). Moreover, in pulp and paper industry, the pulping and subsequent $\mathrm{H}_{2} \mathrm{O}_{2}$ bleaching processes are normally carried out around the temperature of $70-80^{\circ} \mathrm{C}$ (Sundara 1998). Fluctuated temperatures could cause fiber damage and pulp yield loss (Süss et al. 1996). Therefore, the condition of rice straw pulp pretreatment by xylanase in this study was set at $70^{\circ} \mathrm{C}$. The effect of xylanase pretreatment on the pulp characteristics is summarized in Table 5. A

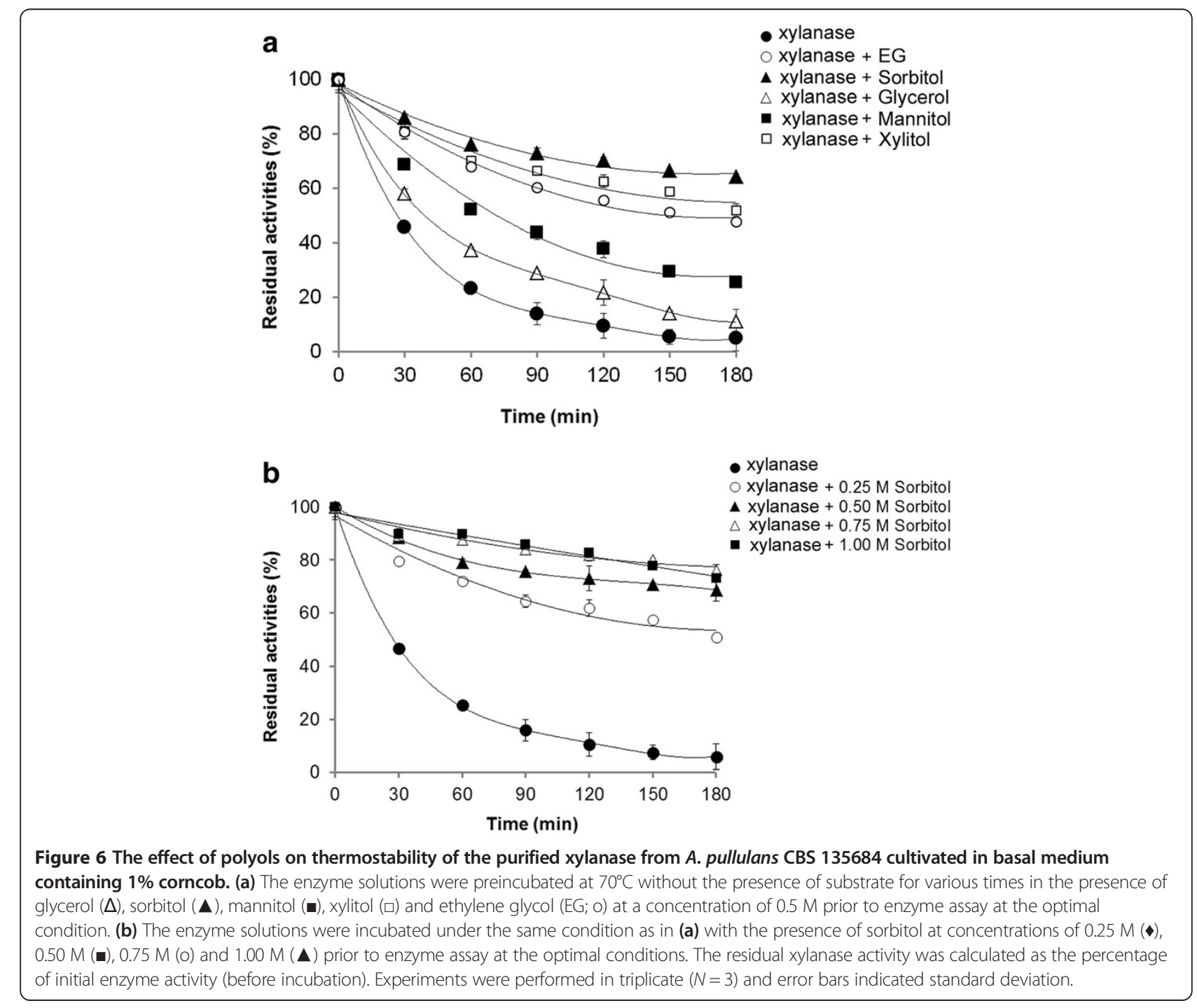


Table 5 The effect of xylanase pretreatment on the physical and optical properties of rice straw pulp

\begin{tabular}{|c|c|c|c|c|c|c|c|}
\hline Treatment & $\begin{array}{l}\text { Brightness } \\
\text { (ISO Units)* }\end{array}$ & $\begin{array}{l}\text { Tensile index } \\
\left(\mathrm{N} \cdot \mathrm{m} \mathrm{g}^{-1}\right)^{*}\end{array}$ & $\begin{array}{l}\text { Tear index } \\
\left(\mathrm{mN} \cdot \mathrm{m}^{2} \mathrm{~g}^{-1}\right)^{*}\end{array}$ & $\begin{array}{l}\text { Fiber length } \\
(\mathrm{mm})^{*}\end{array}$ & $\begin{array}{c}\text { Fines content } \\
(\%)^{*}\end{array}$ & $\begin{array}{l}\text { Fiber curl } \\
\text { index* }\end{array}$ & $\begin{array}{c}\text { Fiber kink } \\
\text { index* }\end{array}$ \\
\hline Untreated & $39.5 \pm 0.10^{a}$ & $39.8 \pm 5.90$ & $7.68 \pm 0.50^{\mathrm{a}}$ & $0.93 \pm 0.05$ & $49.3 \pm 0.34^{a}$ & $0.07 \pm 0.002^{a}$ & $1.48 \pm 0.04^{\mathrm{a}}$ \\
\hline $\mathrm{H}_{2} \mathrm{O}_{2}$ & $55.5 \pm 1.00^{\mathrm{b}}$ & $35.8 \pm 7.00$ & $6.56 \pm 0.61^{a}$ & $1.01 \pm 0.05$ & $45.2 \pm 0.14^{b}$ & $0.07 \pm 0.003^{\mathrm{a}}$ & $1.42 \pm 0.03^{b}$ \\
\hline Xylanase $+\mathrm{H}_{2} \mathrm{O}_{2}$ & $62.8 \pm 0.40^{c}$ & $42.4 \pm 3.90$ & $12.2 \pm 0.75^{b}$ & $0.93 \pm 0.05$ & $40.6 \pm 0.90^{c}$ & $0.09 \pm 0.002^{b}$ & $1.59 \pm 0.02^{c}$ \\
\hline Xylanase + Sorbitol $+\mathrm{H}_{2} \mathrm{O}_{2}$ & $63.0 \pm 0.58^{c}$ & $46.3 \pm 4.90$ & $13.1 \pm 1.30^{\mathrm{b}}$ & $1.00 \pm 0.16$ & $39.7 \pm 0.30^{c}$ & $0.10 \pm 0.008^{c}$ & $1.65 \pm 0.02^{d}$ \\
\hline
\end{tabular}

All treatments were incubated in $50 \mathrm{mM}$ of sodium acetate buffers $\left(\mathrm{pH} \mathrm{6.0)}\right.$ ) at $70^{\circ} \mathrm{C}$ for $2 \mathrm{~h}$ for pretreatment and bleached at the same temperature for $1 \mathrm{~h}$. The crude xylanase (18.6 $\mathrm{U} \mathrm{g}^{-1}$ dry pulp) used in prebleaching experiment was obtained from A. pullulans CBS 135684 cultivated in basal medium containing $1 \%$ (w/v) corncob. Sorbitol $(0.75 \mathrm{M})$ and $\mathrm{H}_{2} \mathrm{O}_{2}(10 \%(\mathrm{v} / \mathrm{v}))$ were used in the respective experiment.

*Mean \pm one standard deviation derived from three replicates $(N=3)$. Different superscript letter $(a, b, c)$ in the same column indicated the values were significantly different (ANOVA and DMRT, $P<0.05$ ).

significant (1.13-fold) increase in pulp brightness was observed with pretreatment of the rice straw pulp with either xylanase or xylanase plus $0.75 \mathrm{M}$ sorbitol, compared to those of the pulp treated with $\mathrm{H}_{2} \mathrm{O}_{2}$ alone and the unbleached pulp. Increasing pulp brightness after xylanase bleaching was previously reported in bagasse pulp (Kulkarni and Rao 1996), and has been suggested to be caused by the selective hydrolysis of xylan on the fiber surfaces, which facilitates the subsequent $\mathrm{H}_{2} \mathrm{O}_{2}$ penetration into the fibers, leading to the release of lignin. The addition of $0.75 \mathrm{M}$ sorbitol to the crude enzyme solution significantly increased the amount of reducing sugars released in the reaction mixture to $46.6 \pm 3.05 \mu$ mole compared to $41.1 \pm 1.3 \mu$ mole that was released from the pulp pretreated with the crude xylanase alone. The release of reducing sugars could have indicated the efficiency of xylan degradation. At the same time, xylanase pretreatment enhances the removal of transition metal ions, such as iron, manganese, magnesium and calcium, which cause the formation of colored metallic complexes in the carbohydrates (Kirk and Jeffries 1996).

From the observation of fiber morphology, no significant changes were noticed in the fiber length while the fines content was decreased by the xylanase-pretreatment of the pulp. The lower fines content led to the higher numeric average of fiber length and thus the paper strength was enhanced (Liu et al. 2012). In general, the strength of paper is influenced by the fiber morphology which can be adversely affected by the kink and curl of fibers (Page 1969). However, in this study, the paper strength, in terms of the tear and tensile indexes, increased along with the curl and kink indexes of the fibers after xylanase pretreatment. This may be due to the digested fibers becoming more flexible, thus the moderate curl of the fibers could enhance the interweaving between them which led to the strengthened bonding between the pulp fibers (Liu et al. 2012) These results clearly indicated that the crude xylanase from A. pullulans CBS 135684 had potential for treatment of rice straw before bleaching for paper manufacture since it significantly improved the paper brightness without compromising fiber quality.

\section{Conclusion}

The extracellular xylanase produced by a Thai strain of $A$. pullulans CBS 135684 grown on corncob based media was cellulase-free and showed an enhanced activity at a high temperature $\left(70^{\circ} \mathrm{C}\right)$. The purified enzyme was active over a broad $\mathrm{pH}$ range $(>70 \%$ activity at $\mathrm{pH} 4.0-10.0$, and optimal at $\mathrm{pH}$ 6.0) which was uncommon among yeasts. The negative entropy change at all temperatures suggested that xylanase proceeds towards compaction during denaturation. The thermostability of the enzyme at high temperatures was improved by $0.75 \mathrm{mM}$ sorbitol supplementation in the enzyme preparation. In the bleaching of rice straw fibers, enzyme pretreatment prior to $\mathrm{H}_{2} \mathrm{O}_{2}$ mediated bleaching significantly increased the fiber brightness and boosted the bleaching effect of $\mathrm{H}_{2} \mathrm{O}_{2}$. This new thermophilic xylanase from A. pullulans CBS 135684 has potential for use in the bleaching of rice straw fibers.

\section{Competing interests}

The authors declare that they have no competing interests.

\section{Authors' contributions}

WB: Writing of the manuscript and data acquisition. PL and SP: Revision of the manuscript and data interpretation. SC: Supervision. DEE and SWK: Revision of the manuscript and supervision. HP: Revision of the manuscript, data interpretation and supervision. All authors read and approved the final manuscript.

\section{Acknowledgements}

This work was financially supported by the Ratchadaphiseksomphot Endowment Fund of Chulalongkorn University (RES560530024-EN) and Eveleigh-Fenton Fund (Rutgers University).

\section{Author details}

${ }^{1}$ Biological Sciences Program, Faculty of Science, Chulalongkorn University, Chulalongkorn, Bangkok 10330, Thailand. Plant Biomass Utilization Research Unit, Department of Botany, Faculty of Science, Chulalongkorn University, Chulalongkorn, Bangkok 10330, Thailand. ${ }^{3}$ Department of Imaging and Printing Technology, Faculty of Science, Chulalongkorn University, Chulalongkorn, Bangkok 10330, Thailand. ${ }^{4}$ Department of Biochemistry and Microbiology, School of Environmental and Biological Sciences, Rutgers University, Rutgers, NJ 08901-8525, USA. ${ }^{5}$ Department of Chemical and Biological Engineering, Korea University, Seoul 136-701, Republic of Korea.

Received: 1 November 2013 Accepted: 14 January 2014 Published: 18 January 2014 


\section{References}

Anema SG, McKenna AB (1996) Reaction kinetics of thermal denaturation of whey proteins in heated reconstituted whole milk. J Agric Food Chem 44:422-428

Arrhenius S (1889) Quantitative relationship between the rate a reaction proceed and its temperature. J Phys Chem 4:226-248

Atlas RM (1993) Handbook of microbiological media. In: Parks LC (ed) CRC Press, Boca Raton, Florida, USA

Bailey MJ, Biely P, Poutanen K (1992) Interlaboratory testing of methods for assay of xylanase activity. J Biotechnol 23:257-270

Beg QK, Kapoor M, Mahajan L, Hoondal GS (2001) Microbial xylanases and their industrial applications: a review. Appl Microbiol Biotech 56:326-338

Benedetti ACEP, da Costa EP, Aragon CC, dos Santos AF, Goulart AJ, Attili-Angelis D, Monti Andréa R (2013) Low-cost carbon sources for the production of a thermostable xylanase by Aspergillus niger. Rev Ciênc Farm Básica Apl 34(1):25-31

Bourneow C, Benjakul S, Kittikun H, Impact A (2012) Impact of some additives on the stability of microbial transglutaminase from Providencia sp. C1112. As J Food Ag-Ind 5(03):226-233

Breccia JD, Moran AC, Castro GR, Sineriz F (1998) Thermal stabilization by polyols of beta-xylanase from Bacillus amyloliquefaciens. J Chem Technol Biotechnol 71(3):241-245

Chaiarrekij S, Apirakchaiskul A, Suvarnakich K, Kiatkamjornwong S (2011) Kapok 1: Characteristics of kapok fibre as a potential pulp source for paper making. BioRes 7(1):475-488

Cobos A, Estrada P (2003) Effect of polyhydroxylic co solvents on the thermostability and activity of xylanase from Trichoderma reesei QM 9414. Enzyme Microbial Technol 33:810-818

Costa SA, Tzanov T, Carneiro AF, Paar A, Gübitz GM, Cavaco-Paulo A (2002) Studies of stabilization of native catalase using additives. Enzyme Microb Tech 30:387-391

Cui L, Du G, Zhang D, Chen J (2008) Thermal stability and conformational changes of transglutaminase from a newly isolated Streptomyces hygroscopicus. BioRes 99:3794-3800

Do TT, Quyen TD, Dam TH (2012) Purification and characterization of an acidstable and organic solvent-tolerant xylanase from Aspergillus awamori VTCC-F312. ScienceAsia 38(2012):157-165

Fu D, Li C, Lu J, Rahman A, Tan T (2010) Relationship between thermal inactivation and conformational change of Yarrowia lipolytica lipase and the effect of additives on enzyme stability. J Mol Catalysis B-Enzymatic 66:136-141

George SP, Ahmad A, Rao MB (2001) A novel thermostable xylanase from Thermomonospora sp.: influence of additives on thermostability. BioRes 78(3):221-224

Goering HK, Van Soest PJ (1970) Forage Fiber Analysis (apparatus, reagents, procedures and some applications). In: Agricultural Handbook No. 379. Agriculture Research Service USDA, Washington (DC), USA

Gummadi SN (2003) What is the role of thermodynamics in protein stability? Biotechnol Bioprocess Eng 8:9-18

Höijea A, Gröndahla M, Tømmeraasb K, Gatenholma P (2005) Isolation and characterization of physicochemical and material properties of arabinoxylans from barley husks. Carbohydr Polym 61(3):266-275

Kang-li F, Da-nian L (2013) Polyols' effect on thermal stability of lipase and its application in cotton fabrics' enzymatic treatment. J Text I 104(11):1206-1212

Kirk TK, Jeffries TW (1996) Enzymes for Pulp and Paper Processing. In: Jeffries TW, Viikari $L$ (eds) Role of microbial enzymes in pulp and paper processing, 655th edn. ACS Syrup Ser, pp 2-14

Kulkarni N, Rao M (1996) Application of xylanase from alkaliphilic thermophilic Bacillus sp. NCIM 59 in bio-bleaching of bagasse pulp. J Biotechnol 51:167-173

Laemmli UK (1970) Cleavage of structural proteins during the assembly of the head of bacteriophage T4. Nature 227:680-685

Lama L, Calandrelli V, Gambacorta A, Nicolaus B (2004) Purification and characterization of thermostable xylanase and beta-xylosidase by thermophilic bacterium Bacillus thermantarcticus. Res Microbiol 155:283-289

Leathers TD (1986) Color Variants of Aureobasidium pullulans overproduce xylanase with extremely high specific activity. Appl Environ Microbiol 52:1026-1030

Leathers TD (1989) Purification and properties of xylanase from Aureobasidium. J Ind Microbiol 4:341-348

Lemos JLS, Bon EPS, Santana MFE, Junior NP (2000) Thermal stability of xylanases produced by Aspergillus awamori. Brazilian J Microbiol 31:206-211

Li XL, Zhang ZQ, Dean JF, Eriksson KE, Ljungdahl LG (1993) Purification and characterization of a new xylanase (APX-II) from the fungus Aureobasidium pullulans Y-2311-1. Appl Environ Microbiol 59:3212-3218
Liu N, Qin M, Gao Y, Li Z, Fu Y, Xu Q (2012) Pulp properties and fiber characteristics of xylanase-treated aspen APMP. BioRes 7:3367-3377

Lowry OH, Rosenbrough NJ, Farr AL, Randal RJ (1951) Protein measurement with the Folin reagent. J Biol Chem 193:265-275

Manitchotpisit P, Leathers TD, Peterson SW, Kurtzman CP, Li X-L, Eveleigh DE, Lotrakul P, Prasongsuk S, Dunlap CA, Vermillion KE, Punnapayak H (2009) Multilocus phylogenetic analyses, pullulan production and xylanase activity of tropical isolates of Aureobasidium pullulans. Mycol Res 113:1107-1120

Marangoni AG (2003) Enzyme kinetics: a modern approach. John Wiley and Sons, New Jersey

Miller GL (1959) Measurement of reducing sugar by DNS reagent. Anal Chem $31: 426-428$

Ohta K, Fujimoto H, Fujii S, Wakiyama M (2010) Cell-associated $\beta$-xylosidase from Aureobasidium pullulans ATCC 20524: Purification, properties, and characterization of the encoding gene. J Biosci Bioengin 110:152-157

Page DH (1969) A theory for the tensile strength of paper. TAPPI 52:674-681

Pal A, Khanum F (2010) Characterizing and improving the thermostability of purified xylanase from Aspergillus niger DFR-5 grown on solid-state-medium. J Biochem Technol 2:203-209

Parachin NS, Siqueira S, de Faria FP, Torres FAG, de Moraes LMP (2009) Xylanase from Cryptococcus flavus isolate 1-11: Enzymatic profile, isolation and heterologous expression of CXXYN1 in Saccharomyces cerevisiae. J Mol Catalysis 59:52-57

Rani DS, Nand K (2000) Production of thermostable cellulase-free xylanase by Clostridium absonum CFR-702. Process Biochem 36:355-362

Reis D, Costa M, Peralta R (2003) Xylanase production by a wild strain of Aspergillus nidulans. Acta Scientiarum: Biol Sci 25:221-225

Rodrígueza A, Morala A, Serranoa L, Labidib J, Jiméneza L (2008) Rice straw pulp obtained by using various methods. Biores Technol 99:2881-2886

Sadana A (1995) Biocatalysis: fundamentals of deactivation kinetics. Prentice Hall, New Jersey, USA

Samborska K, Guiavarch Y, Van Loey A, Hendrickx M (2006) The thermal stability of Aspergillus oryzae alpha-amylase in presence of sugars and polyols. J Food Process Eng 29:287-303

Sundara R (1998) Hot peroxide bleaching. Can Chem News 50(1):15-17

Süss HU, Nimmerfroh NF, Mambrim FO (1996) TCF bleaching of eucalyptus kraft pulp- the selection of the right sequence and the best conditions. TAPPI Intern, Pulp Bleaching Conf. Proceeding., pp 253-260

Suurnäkki A, Niku-Paavola M-L, Buchert J, Viikari L (2004) Enzymes in pulp and paper processing. In: Aehle W (ed) Enzymes in Industry. Wiley-VCH, Weinheim, pp 232-244, 437-439

Tanaka H, Muguruma M, Ohta K (2006) Purification and properties of a family-10 xylanase from Aureobasidium pullulans ATCC 20524 and characterization of the encoding gene. Appl Microbiol Biotechnol 70:202-211

Techapun C, Charoenrat T, Poosaran N, Watanabe M, Sasak K (2002) Thermostable and alkaline-tolerant cellulase-free xylanases produced from thermotolerant Streptomyces sp. Ab106J. J Biosci Bioeng 93:431-433

Vadi RM, Strohfus BRH, West TP (1996) Characterisation of a xylanase from Aureobasidium pullulans. Microbios 85:179

Viikari L, Poutanen K, Tenkanen M, Tolan JS (2002) Hemicellulases. In: Flickinger MC, Drew SW (eds) Encyclopedia of Bioprocess Technology: Fermentation, Biocatalysis, and Bioseparation. John Wiley \& Sons, Inc, Chichester

Viikari L, Alapuranen M, Puranen T, Vehmaanperä J, Siika-aho M (2007) Thermostable enzymes in lignocellulose hydrolysis. Adv Biochem Eng Biotechnol 108:121-145

Voragen AGJ, Gruppen H, Verbruggen MA, Vietor RJ (1992) Characterization of cereals arabinoxylans: Xylan and Xylanases. Elsevier, Amsterdam

Zheng L, Du Y, Zhang J (2000) Biobleaching effect of xylanase preparation from an alkalophilic Bacillus sp. on ramie fibers. Biotechnol Letters 22:1363-1367

Zhou C, Wang Y, Wu M, Wang W, Li D (2009) Expression of xylanase II from A. usamii in P. pastoris. Food Technol Biotechnol 47(1):90-95

Zimbardi AL, Sehn C, Meleiro LP, Souza FH, Masui DC, Nozawa MS, Guimarães LH, Jorge JA, Furriel RP (2013) Optimization of $\beta$-glucosidase, $\beta$-xylosidase and xylanase production by Colletotrichum graminicola under solid-state fermentation and application in raw sugarcane trash saccharification. Int J Mol Sci $14: 2875-2902$

doi:10.1186/2193-1801-3-37

Cite this article as: Bankeeree et al:: Effect of polyols on thermostability of xylanase from a tropical isolate of Aureobasidium pullulans and its application in prebleaching of rice straw pulp. SpringerPlus 2014 3:37. 